\title{
O ensino de português brasileiro na Argentina sob uma perspectiva intercultural
}

\section{The teaching of brazilian portuguese in Argentina from an intercultural perspective}

\section{La enseñanza de portugués de Brasil en Argentina en una perspectiva intercultural}

\author{
iD (9) Natasha Susmaga Vargas \\ Saint Margaret School, San Antonio de Belen, Heredia, Costa Rica. \\ E-mail: natysusmaga@hotmail.com \\ iD Isabel Cristina Michelan de Azevedo \\ Universidade Federal de Sergipe (UFS), Departamento de Letras Vernáculas (DLEV), São \\ Cristóvão, Sergipe, Brasil. \\ E-mail: icmazevedo2@gmail.com
}

Resumo: O artigo discute o ensino de português como língua estrangeira (PLE) em viés intercultural e parte da expansão do ensino de PLE na Argentina. Para tanto, analisaremos o Brasil Intercultural (2014), elaborado sob a coordenação de Edleise Mendes. Assim, selecionamos atividades de leitura, a fim de investigar se o livro didático (LD) pode favorecer um ensino intercultural (KRAMSCH, 1993; 2009; 2017 [2013]). Por meio de uma metodologia documental e qualitativa, realizamos uma análise interpretativa. Os resultados do trabalho apontaram que as propostas didáticas orientam a comparação entre-culturas, mas não há discussões acerca das aproximações e diferenças culturais de modo crítico e reflexivo. Palavras-chave: Leitura. Interculturalidade. Livro didático. Português como Língua Estrangeira. 
Abstract: The paper discusses Portuguese as a foreign language (PLE) teaching from an intercultural perspective using PLE teaching in Argentina as its base. For this purpose, Brasil Intercultural (2014), produced under the coordination of Edleise Mendes, is analyzed. Thus, reading activities were selected in order to see if they offer the possibility of intercultural teaching (KRAMSCH, 1993; 2009; 2017 [2013]). An interpretive analysis was used based on the qualitative methodology. The results of the research pointed out that didactic proposals guide the comparison between cultures, however, they do not contribute to discussions of cultural differences in a critical and reflective way.

Keywords: Reading. Interculturality. Textbook. Portuguese as a foreign Language.

Resumen: El artículo aborda la enseñanza del portugués comolengua extranjera (PLE) en el sesgo intercultural y parte de la expansión de la enseñanza de PLE en Argentina. Para eso, analizaremos el Brasil Intercultural (2014), elaborado bajo la coordinación de Edleise Mendes. Así, seleccionamos actividades de lectura, a fin de investigar si el LD puede favorecer una enseñanza intercultural (KRAMSCH, 1993; 2009; 2017 [2013]). Por medio de una metodología documental y cualitativa, realizamos un análisis interpretativo. Los resultados de investigación señalaron que las propuestas didácticas orientan la comparación entre culturas, pero no discusiones de las aproximaciones y diferencias culturales de modo crítico y reflexivo.

Palabras clave: Lectura. Interculturalidad. Libro didáctico. Portugués como lengua extranjera.

Submetido em 30 de julho de 2019.

Aceito em 17 de outubro de 2019.

Publicado em 18 de março de 2020. 


\section{Introdução}

Historicamente, o ensino de línguas, seja materna, seja estrangeira, tem sido influenciado pela orientação encontrada no livro didático (doravante LD), por isso, conforme Diniz et al. (2009, p. 265), podemos percebê-lo como um instrumento de poder que, por vezes, "acaba afetando - ou mesmo determinando - o planejamento, os objetivos da aprendizagem, as competências a serem priorizadas, os conteúdos a serem trabalhados e os tipos de atividades a serem propostas" em sala de aula.

No que se refere ao ensino de português como língua estrangeira (PLE), a situação é ainda mais frágil, pois, de acordo com os autores, muitos cursos são organizados e desenvolvidos por professores com pouca ou nenhuma formação específica em língua portuguesa, o que pode influenciar a opção por utilizar um LD, mesmo quando são observadas falhas que comprometem uma aprendizagem de uma determinada língua. Ao tratar especificamente do ensino de leitura, observa-se que a maioria dos LDs de PLE “[...] concebe a leitura não como uma habilidade a ser trabaIhada e ensinada, mas simplesmente avaliada" (DINIZ et al., 2009, p. 234).

Por considerar que a leitura em perspectiva intercultural se associa à cultura produzida por sujeitos em interação na sociedade, entende-se que a interpretação é um produto decorrente das múltiplas influências que atravessam os espaços sociais, o que permite posicionar os sujeitos diferentemente. Vale a pena destacar que isso se torna possível por meio da linguagem e de contatos e trocas realizadas nas dinâmicas relações estabelecidas entre os diversos grupos sociais, considerando também o modo como cada um constrói significados. Nesse sentido, a cultura é compreendida como uma "construção social, produto do eu e de outras percepções" (KRAMSCH, 1993, p. 205, tradução nossa).

Tomar a cultura como construção social é um meio para que sejam evitados o reforço dos estereótipos e a homogeneização 
das culturas, o que permite a manutenção de um enfoque apoiado em características nacionais globais, podendo envolver aspectos como raça, religião, etnicidade, idade ou gênero, sem que haja profundidade histórica. Um processo articulado de compreensão da cultura permite uma visão mais abrangente, que procura superar os limites das atitudes, crenças e visões de mundo limitadas a certos padrões socioculturais (KRAMSCH, 2017 [2013]).

Assim, para discutir a temática abordada anteriormente em uma coleção didática produzida na Argentina para ensinar a língua portuguesa falada no Brasil, este trabalho, com base em uma pesquisa documental de cunho qualitativo, organiza-se em cinco seções. Após a introdução, na seção 1, “O português brasileiro na Argentina", as condições que possibilitaram a publicação da coleção "Brasil Intercultural" foram apresentadas. Para isso, construiu-se um panorama histórico do ensino de PLE na Argentina, apoiado em Cristofoli (2010) e em documentos produzidos no âmbito do MERCOSUL e do MERCOSUL Educacional. Na mesma seção, na subseção 1.2, "Os livros didáticos de PLE elaborados na Argentina", apresentou-se a referida coleção, levando em consideração a sua composição, a abordagem privilegiada e a circulação dentro da Argentina.

Na seção 2, "O ensino de língua estrangeira sob uma perspectiva intercultural", foram recolhidos os conceitos centrais da interculturalidade (KRAMSCH, 1993; 2009; 2017 [2013]). Na seção 3, delineou-se a metodologia da pesquisa, bem como os critérios de seleção para a constituição do corpus e as categorias de análise preestabelecidas com base nos fundamentos da interculturalidade. E, por fim, na seção 4, há a análise de algumas atividades de leituras, o que antecede as considerações finais deste artigo.

\section{O português brasileiro na Argentina}

Com as mudanças significativas na geopolítica nos anos de 1990, a América Latina começa a sentir os efeitos da iminente glo- 
balização mundial. Nesse contexto, o Brasil e a Argentina passam a ver um ao outro como possíveis parceiros comerciais para enfrentar os novos desafios econômicos decorrentes da globalização dos mercados e, assim, surge o MERCOSUL.

Consequentemente, foram promulgadas leis que estabelecem políticas de Estado em relação às línguas, que são produto de processos de integração regional, em particular, no MERCOSUL. Destaca-se o Tratado de Assunção (26 de março de 1991), declarando como idiomas oficiais o espanhol, o português brasileiro e o guarani. Este acordo foi firmado por Estados membros, como a Argentina e o Brasil, juntamente com o Paraguai e o Uruguai.

Com o Tratado de Assunção, percebemos uma planificação linguística que incentiva o uso do espanhol e do português como medida eficaz para reforçar a identidade regional. O bloco propôs medidas de integração educativas, culturais e linguísticas, como a elaboração de um protocolo de intenções dos Ministros da Educação, que se interessava em difundir a aprendizagem dos idiomas oficiais - espanhol e português - nos sistemas educacionais, em todos os níveis e modalidades. Ademais, na perspectiva de único país com língua portuguesa oficial no MERCOSUL, o Brasil encontrou espaço favorável para delinear uma política linguística e educacional com vistas à valorização geopolítica e social do português brasileiro (PB).

Para complementar o Tratado de Assunção, surge o primeiro documento que estabelece as bases institucionais do MERCOSUL, o Protocolo de Ouro Preto (1994). A partir desse documento, o bloco consolida seu caráter intergovernamental e define sua estrutura institucional. Consequentemente, houve uma maior atenção às questões educativas, tanto no Brasil com a aprovação da nova Lei de Diretrizes e Bases da Educação (LDB), em 1996, quanto na Argentina com a elaboração dos Contenidos Básicos Comunes para la Educación General Básica (CBC) em 1995, documento voltado ao ensino de línguas estrangeiras com foco na comunicação.

No contexto de integração regional entre os países, ocorre a assinatura do "acordo de Integração Cultural entre o Brasil - Argentina", 
no ano de 1997. Nesse mesmo ano, é criado o Setor Educacional MERCOSUL (SEM) e a "Asociación Argentina de Profesores de Portugués"1 $^{\prime \prime}$ (AAPP), sendo que esta última tem desempenhado um papel de destaque nos esforços nacionais para a sanção de leis sobre a incorporação do português ao currículo escolar e à formação de professores.

No ano seguinte, é elaborado o primeiro documento para o Setor Educacional, o Plano Trienal (1998 - 2000), definido a partir de interesses comuns entre os países-membros, como a compatibilização de aspectos curriculares e a inclusão no ensino médio das línguas oficiais do MERCOSUL. Nesse período, houve a criação do "Novo Convênio de Integração Cultural com o Brasil", que comprometia o país a difundir o idioma português e a cultura da República Federativa do Brasil, e a aprovação de um "Programa de Português a distância", com o intuito de formar profissionais para o ensino de português.

Com a nova organização do SEM, a partir do ano de 2001, observam-se avanços na elaboração sistemática de documentos, como o decreto da lei 11.161/2005, sancionada pelo presidente Luis Inácio Lula da Silva, que instaura a obrigatoriedade da oferta do ensino de língua espanhola no ensino médio. Nesse mesmo ano na Argentina, o SEM estabelece o plano de ação de 2006-2010, com o objetivo de contribuir para a integração regional, no âmbito da educação, da cidadania e cultura. Ainda, como meta, são criados centros de estudos de língua e literatura dos idiomas oficiais do MERCOSUL (CRISTOFOLI, 2010). Nesse contexto, quando sancionada na Argentina a Lei 26.206/2006, configura-se "a obrigatoriedade de conteúdos curriculares de LE relacionados ao MERCOSUL".

Três anos depois, com a aprovação da lei 26.468/2008, torna-se obrigatória a oferta da disciplina do PLE optativa no sistema educativo nacional. Entretanto, sua obrigatoriedade no ensino secundário na Argentina parece estar mais relacionada aos compromissos preexistentes com o Brasil, decorrentes dos acordos bilaterais e das recomendações no âmbito supranacional, em detrimento

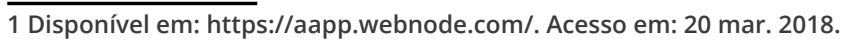


do cumprimento das sugestões provenientes de documentos do MERCOSUL Educacional.

Dando continuidade ao plano anterior, o SEM (2011-2015) cria a Comissão Regional Coordenadora de Formação Docente (CRC FD), responsável pela formação de professores de português e espanhol e pela instalação dos programas de "profesorados" nas universidades públicas e nos institutos argentinos de formação docente. Sucedido pelo Plano SEM (2016-2020), em vigência, observam-se, com base nas atas das reuniões relacionadas à formação docente, as circunstâncias que afetam o ensino de línguas e como o setor é desenvolvido.

Vinculado ao CRC FD, surge o Programa de Apoio ao Setor Educacional do MERCOSUL (PASEM), que abrange universidades públicas e privadas vinculadas aos Ministérios de Educação da Argentina e do Brasil, e tem como finalidade promover a integração e a regionalização da educação superior, além de fortalecer a formação docente. Por isso, universidades são convidadas a promover a oferta acadêmica de formação de professores de PLE e a possibilidade de obtenção de certificado de níveis de proficiência aos estudantes que se submetessem aos exames de avaliação presencial e concluíssem a proposta curricular.

Atualmente, no que diz respeito ao ensino de línguas na Argentina, há cursos de licenciatura, chamados de "Profesorado", que têm como objetivo formar novos profissionais em diferentes línguas estrangeiras e em PLE. As instituições estão distribuídas nas variadas províncias, como demonstrado no quadro a seguir. 
Quadro 1 - Institutos de Ensino Superior com “Profesorados” de PLE

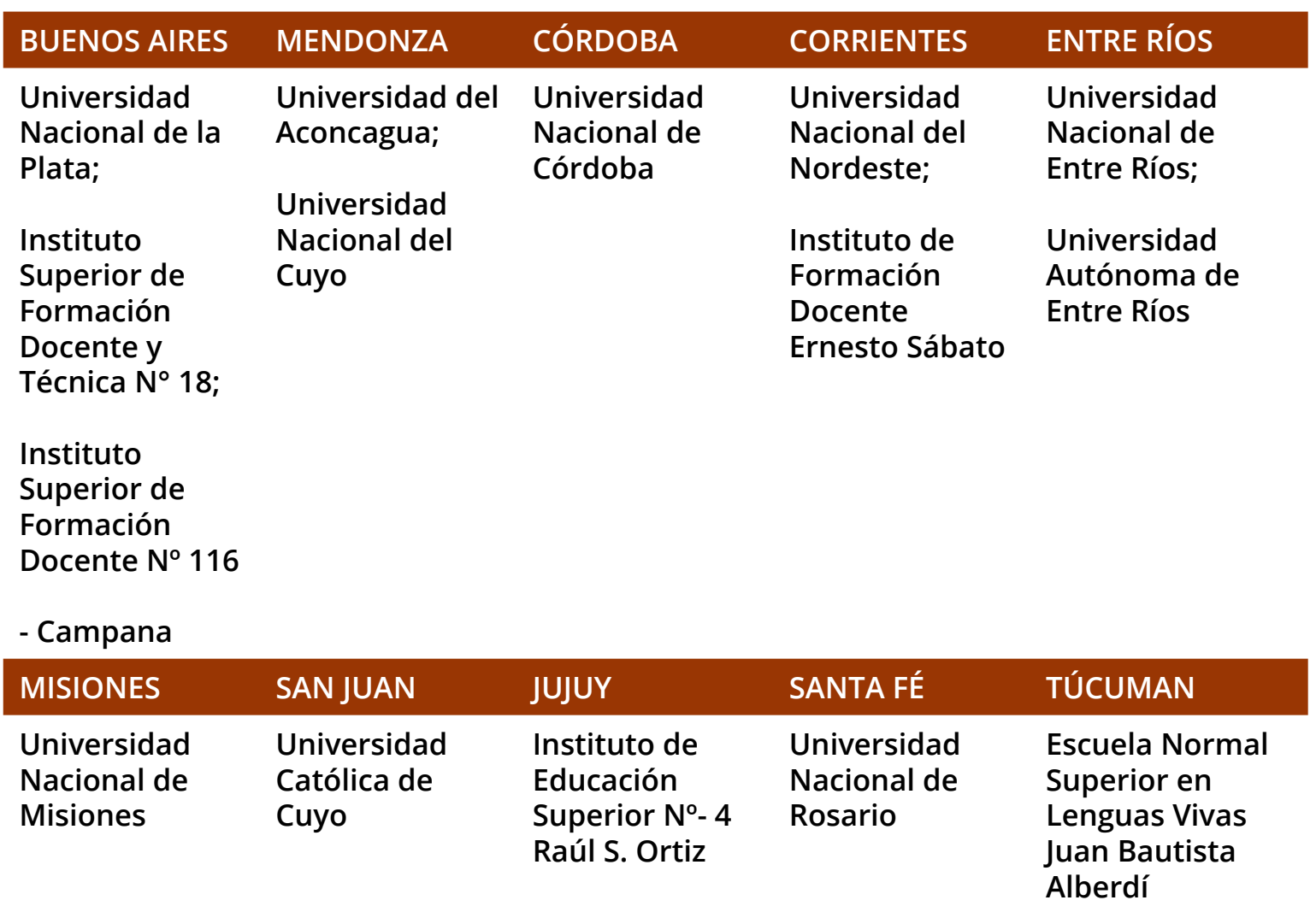

Fonte: Elaborado com base em informações disponibilizadas pelo site da Secretaria de Políticas Universitárias do Governo Argentino e pelo portal eletrônico da Asociácion Argentina de Profesores de Portugués. Acesso em: 11 jun. 2018.

É preciso esclarecer que um dos institutos mais conhecidos e renomados, o Centro Cultural Brasil-Argentina (CCBA)², não oferece mais o curso de "profesorado". Somente há os Institutos Lenguas Vivas "Juán Jámon Fernandéz" e "Sofia Esther B. de Spangenberger", que aparentemente estão vinculados ao Instituto Camões ${ }^{3}$ e objetivam difundir o português europeu e a cultura portuguesa. Nesse cenário, também podem ser identificadas algumas ações promovidas por instituições privadas pelo ensino de português em nível de escolarização e cursos livres na Argentina, como a "Casa do Brasil".

\footnotetext{
2 É a unidade da Rede Brasil Cultural responsável pela difusão, na Argentina, da língua portuguesa e da cultura brasileira. Criado em 2014, pelo Ministério das Relações Exteriores, por meio de seu Departamento Cultural e da Embaixada do Brasil em Buenos Aires, o CCBA propõe-se a aproximar ainda mais a cultura brasileira da sociedade argentina. Disponível em: http://ccba. itamaraty.gov.br/pt-br/. Acesso em: 23 maio 2018.

30 Instituto Camões assegura o ensino da língua e cultura portuguesas em nível do ensino superior, em diversos países, por meio de sua rede de leitorados, em cooperação com instituições de ensino superior e organizações internacionais. Disponível em: http://www.instituto-camoes.pt/. Acesso em: 23 maio 2018.
} 
Percebe-se, ainda, que os poucos incentivos do governo do Brasil para promover o português brasileiro não favorecem a consolidação das políticas linguísticas, como acontece com as ações do Instituto Camões, que possui um trabalho contínuo e colabora com o desenvolvimento das políticas linguísticas de Portugal. O Instituto Machado de Assis, organizado no Brasil, é o exemplo de uma das ações interministeriais bloqueadas pelo Ministério das Relações Exteriores. A dificuldade de se criar efetivamente o instituto diz respeito não apenas a entraves institucionais, mas também a equívocos constitutivos da política linguística exterior brasileira.

Ademais, o Brasil não conta com um documento oficial para a orientação de ensino de português como língua estrangeira, nem possui critérios de análise de materiais didáticos desse tipo. Diversamente da América Latina, a Comunidade Europeia elabora o Quadro Europeu Comum de Referências para Línguas (CONSELHO DA EUROPA, 2001)4, que estabelece um padrão europeu e os princípios norteadores para o ensino de LE. Portugal, especificamente, cria o Quadro de Referências para o Ensino de Português no Estrangeiro (QuaREPE) em 2011, voltado especificamente ao ensino do PLE. Destacamos que esses documentos se preocupam com a representação linguística do português na lusofonia. Observamos, então, não haver uma política claramente definida em relação ao ensino de português brasileiro, o que é um ponto crítico, pois percebe-se que não há o fortalecimento de um projeto nacional apoiado em uma variante específica em relação às outras línguas estrangeiras.

Por parte do Brasil, observam-se alguns programas direcionados a incentivar os estudantes estrangeiros a estudar no Brasil, como o PEC-G (voltado à graduação), o PEC-PG (voltado à pós-graduação) e o Programa de Alianças para a Educação e Capacitação (PAEC), também vinculado à pós-graduação. Já para professores brasileiros que desejam ensinar o português no exterior há um

\footnotetext{
4 Documento que estabelece um padrão para o ensino das línguas modernas, inclusive o português, mas no contexto europeu. Esse documento apresenta uma matriz de análise do uso da língua e estabelece as competências adequadas a cada nível de proficiência linguística (o nível básico, A1, A2; o intermediário, B1, B2; o avançado, C1, C2), além de oferecer uma escala com todos os aspectos esperados dos estudantes em uma dada língua tanto em leitura quanto na escrita e na expressão oral.
} 
programa conhecido como "leitorado", que oferece vagas por meio de um edital, publicado anualmente pelo Itamaraty (MRE).

$\mathrm{Na}$ atual conjuntura política, Brasil e Argentina se configuram como países de economia fragmentada em decorrência das mudanças nos seus respectivos governos. No Brasil, por exemplo, desde o ano de 2016, foi revogada a lei que instituía a obrigatoriedade do ensino de espanhol no ensino médio, vigente a partir do governo Luís Inácio Lula da Silva, e, até o momento atual, nada foi feito para reestabelecer o fortalecimento das políticas linguísticas entre os países-membros. Isso provoca a reflexão de como a relação entre os países tem sido mediada por avanços e retrocessos no que se refere ao movimento de internacionalização da língua.

\section{Os livros didáticos de PLE elaborados na Argentina}

A partir da década de 1990 ocorre a expansão do ensino de PLE na Argentina, o que marca um período desencadeado pelo interesse na elaboração de materiais didáticos. Com isso, algumas instituições privadas na Argentina iniciaram a publicação de seus próprios LDs, na tentativa de atender essa demanda. Nesse contexto, são elaboradas cinco coleções de edição nacional, para o ensino de PLE, voltadas para falantes de espanhol.

Segundo González (2015), no ano de 1997 a Funceb publica a primeira coleção de LD, Um português bem brasileiro (volumes 1 a 4), cuja organização tem por base o conceito de língua como sistema de estruturas. Também de uso local, a mesma instituição publica outro livro no ano seguinte, Conhecendo o Brasil, de nível básico. Entretanto, esses LDs não estão mais disponíveis no mercado.

Entre 2005 e 2010, André e Santa publicam o livro Português Dinâmico, de nível básico e intermediário, para hispanofalantes jovens e adultos. Segundo González (2015), os LDs apresentam traços que evidenciam uma abordagem gramatical, pois as unidades estão organizadas em torno de funções e situações de co- 
municação com exercícios sistemáticos dos tópicos gramaticais e vocabulário.

Ainda em 2010, Almeida e Barbosa publicam Horizontes, que se assume como um material comunicativo e intercultural de acordo com as autoras do livro didático. No entanto, conforme destaca González (2015) em sua pesquisa, esse material “é predominantemente comunicativo, porém devido à forte presença de atividades pré-comunicativas, não pode ser declarado totalmente como uma abordagem comunicativa" (GONZÁLEZ, 2005, p. 127).

No mesmo viés, apoiada em uma proposta de abordagem intercultural e tendo como uma das autoras Cibele Nascente Barbosa, em 2010, é lançada a coleção Brasil Intercultural: Língua e Cultura Brasileira para Estrangeiros (doravante $B /$ ), publicada pela Escola de Línguas Casa do Brasils, sob a coordenação da professora doutora Edleise Mendes. Inicialmente o $B /$ quer atender especificamente às necessidades dessa instituição, por ser constatada a necessidade de um livro didático próprio de acordo com as exigências e características avaliativas do exame Celpe-Bras e com as necessidades dos estudantes e professores da própria e de outras instituições, que manifestavam a insatisfação e falta de identificação com os livros que chegavam do Brasil. Nesse contexto, autoras brasileiras com formação na área de Letras foram convidadas a elaborar a coleção. Pouco depois, a coleção se amplia para o universo de outras escolas dentro da Argentina, como podemos observar no quadro 3.

\footnotetext{
5 Fundada no ano de 1990, tornando-se a primeira instituição privada especializada no ensino de PLE, em Buenos Aires, a casa do Brasil é uma escola de referência para o ensino de Português e a difusão da cultura brasileira, pela qualidade e variedade de cursos oferecidos, tais como: curso preparatório regular, intensivo para cursos de exames Celpe-Bras, cursos para empresas, português para negócios, especialmente concebidos e monitorados de acordo com cada necessidade. Essa instituição oferece ainda aulas particulares e cursos temáticos de literatura, cultura, música, conversação e gramática, redação, bem como promove no plano da Formação Docente Continuada congressos, seminários e cursos para professores. Há, também, a oferta de serviços diversos, incluindo uma permanente programação cultural, e a Biblioteca Jorge Amado e Livraria Casa do Brasil. Disponível em: https://www.casadobrasilar.com. Acesso em: 15 jun. 2018.
} 
Quadro 3 - Instituições que utilizam a coleção Brasil Intercultural na Argentina

\begin{tabular}{|c|c|c|}
\hline BUENOS AIRES & C.A.B.A & CHACO \\
\hline $\begin{array}{l}\text { St. Luke's College; } \\
\text { Secundaria Dover High School; } \\
\text { Colegio Oakhill; } \\
\text { Northfield School; } \\
\text { Colegio Patris; } \\
\text { St. Matthews College; } \\
\text { Programa de Lenguas } \\
\text { (UNSAM); } \\
\text { Colegio Maria Montessori; } \\
\text { Laboratorio de Idiomas } \\
\text { (Universidad de Mar del Plata) }\end{array}$ & $\begin{array}{l}\text { Casa do Brasil - Escola de } \\
\text { Lenguas; } \\
\text { Escuela Argentina Modelo; } \\
\text { Colegio Santo Tomás de } \\
\text { Aquino (UCA); } \\
\text { Instituto Orsino }\end{array}$ & $\begin{array}{l}\text { Departamento de Idiomas } \\
\text { Modernos de la Secretaria } \\
\text { General de Extensión } \\
\text { Universitaria de la } \\
\text { Universidad Nacional del } \\
\text { Nordeste (UNNE) }\end{array}$ \\
\hline CÓRDOBA & CORRIENTES & ENTRE RÍOS \\
\hline $\begin{array}{l}\text { Departamento Cultural de } \\
\text { la Faculdad de Lenguas de } \\
\text { la Universidad Nacional de } \\
\text { Córdoba }\end{array}$ & $\begin{array}{l}\text { Departamento de Idiomas } \\
\text { Modernos de la Secretaria } \\
\text { General de Extensión } \\
\text { Universitaria de la UNNE }\end{array}$ & $\begin{array}{l}\text { Asociación civil Espacios de } \\
\text { Gualeguay }\end{array}$ \\
\hline MISIONES & SAN LUIS & TERRA DEL FUEGO \\
\hline $\begin{array}{l}\text { Proyecto Idiomas (Universidad } \\
\text { Nacional de Misiones) }\end{array}$ & $\begin{array}{l}\text { Centro de Idiomas } \\
\text { (Universidad de La Punta) }\end{array}$ & $\begin{array}{l}\text { Emei Lenguas Extranjeras; } \\
\text { Instituto Provincial de } \\
\text { Idiomas (IPI) }\end{array}$ \\
\hline
\end{tabular}

Fonte: Elaborada com base nas informações do site Brasil Intercultural. Disponivel em: http://www.brasilintercultural. com.ar/institucionesqueutilizanbi.php?sec=Buenos\%20Aires. Acesso em: 12 jun. 2018.

Assim, nota-se que a coleção vem sendo utilizada em variados espaços dentro da Argentina, como: universidades, escolas secundárias, instituições públicas e privadas. Além disso, é somente comercializada no país.

De acordo com o prefácio do LD, a abordagem pedagógica adotada pela coleção é intercultural. Segundo Barbosa e Castro (2014a), aprender uma língua significa um conjunto de possibilidades de interação e vivência que inclui não somente estruturas formais e suas regras, mas engloba todos os significados culturais, históricos e políticos que a constituem. Nesse sentido, ensinar e aprender uma língua de modo intercultural é transformar a sala de aula em um espaço culturalmente sensível, onde o contato entre línguas e culturas diferentes é construído por meio do diálogo 
e da constante reflexão crítica sobre as proximidades e diferenças que as caracterizam. Assim, nota-se que o $B l$, ao se assumir como um LD intercultural, já toma para si uma responsabilidade que indica seu interesse pelas questões culturais, representando um avanço em relação a outros materiais didáticos.

Em relação à composição do LD, cada volume possui oito unidades compostas por uma habilidade linguística, a saber: leitura, compreensão oral, produção oral e escrita. Contudo, conteúdos de gramática, vocabulário e pronúncia estão presentes de forma significativa no material. As unidades ainda contam com textos que se diversificam quanto aos gêneros e nas mais diferentes temáticas.

Além dos livros impressos, a coleção conta com o manual do professor, com áudios e vídeos disponíveis no site. No entanto, em relação à produção do $B I$, vale ressaltar que não há como definir a partir de quais critérios o LD foi elaborado. Isso quer dizer que não foi encontrada nenhuma informação a respeito de orientações que embasaram a construção do material.

No entanto, pensando na possibilidade de utilização da referida coleção para o ensino de PLE sob um viés intercultural, apoiamo-nos principalmente nos pressupostos teóricos de Kramsch (1993; 2009; 2017 [2013]). Na discussão proposta na seção 2, 0 ensino de língua estrangeira sob uma perspectiva intercultural, serão mobilizados os conceitos que permitirão (re)pensar o ensino de LE por meio de uma postura crítica e reflexiva.

\section{O ensino de língua estrangeira sob uma perspectiva in- tercultural}

Historicamente, no ensino de línguas, a cultura era compreendida como informação conduzida pela linguagem, não como uma característica própria dela. Logo, a cultura não era reconhecida como um sistema de significação pela qual fazemos sentido no 
mundo, bem como não era reconhecida a noção de que a aprendizagem da língua ocorre dentro das relações de poder. Mais ainda, reforçava-se a concepção de uma identidade fixa, homogênea e una, o que tem sido criticado por teóricos como Moita Lopes (2002; 2006) e Hall (2009), pois, como apontam os autores, as identidades são fragmentadas.

No intuito de superar as lacunas desse modelo social, e diante da necessidade de (re)pensar o lugar da cultura no ensino de LE, surge a perspectiva intercultural, que advém da visão de que língua e cultura são aspectos indissociáveis, porque considera que, ao aprender uma LE, consequentemente, se aprende os aspectos socioculturais que a envolvem. Esse estudo incentiva a comparação entre a cultura do próprio grupo social e a cultura de outro grupo, como também possibilita a discussão entre as diferenças e semelhanças culturais de modo crítico e reflexivo, em um processo de reavaliação, confronto e negociação (KRAMSCH, 1993).

Kramsch (1993) discute a cultura como um terceiro espaço ${ }^{6}$ a ser construído no ensino de uma língua estrangeira. Para a autora, este termo, muitas vezes, ignora a natureza simbólica do sujeito multilíngue - tanto como um eu que cria significados quanto como um ator social que tem o poder de mudar o seu entorno por meio do uso de múltiplos sistemas simbólicos. O conceito de cultura, atribuído posteriormente por Kramsch (2017 [2013], p. 145), é ressignificado como "[...] um processo discursivo dinâmico, construído e reconstruído de várias maneiras por indivíduos envolvidos nos embates por significado simbólico e no controle de subjetividades e interpretações da história".

Nesse sentido, ao estar imerso em outra língua, o sujeito sofrerá influência da cultura desta língua, visto que, conforme aponta Hall (2009), a identidade do sujeito é construída ao longo de discursos, práticas e posições sociais. Para o autor, isso é possível porque as identidades não são fixas, nem unificadas. "Elas têm a ver com a questão dos recursos da história da linguagem e da cul-

6 Kramsch (1993) analisa o terceiro espaço, apontando para a noção de cultura como limitada a "culturas nacionais". Tal concepção foi reformulada em sua publicação de 1998, ao introduzir o conceito de comunidade discursiva, referindo-se às maneiras como um grupo social usa a linguagem de modo a satisfazer suas necessidades sociais. 
tura para a produção não daquilo que nós somos, mas daquilo que nos tornamos" (HALL, 2009, p. 109). A partir do contato com outra língua, as identidades são reposicionadas.

Segundo Kramsch (2017 [2013], p. 142), "pesquisas sobre o componente cultural do aprendizado de línguas têm se interessado fortemente pela pragmática intercultural e a adequação sociolinguística do uso da língua em seu contexto cultural autêntico". Pensar a interculturalidade nessa perspectiva é desafiador, porque cada estudante é um mundo e cada sala de aula contribui com algo novo a ser trabalhado, discutido e problematizado.

Kramsch (1993) aponta que a classe de ensino de LE é percebida como um espaço onde os sentidos decorrentes da construção da vida social e cultural do leitor são mobilizados no momento da leitura. A partir dessa visão, a leitura não pode ser compreendida sem que haja uma relação extralinguística com os aspectos que envolvem a língua, porque é nesse processo que os estudantes passam a compreender outras formas de perceber a realidade e construir visões de mundo. Ao mesmo tempo que adquirem habilidades funcionais da língua, “[...] realizam releituras, recontagens, múltiplas interpretações de um mesmo texto, vários modos de criação de significado (visual, verbal, gestual, musical) e múltiplas modalidades de expressão (falada, escrita, eletrônica)"”7 (KRAMSCH, 2009, p. 239).

Com base nesse pressuposto, é considerado que o desafio educacional requer reflexão e ação. Kramsch (1993, p. 205-206) aponta dois princípios fundamentais para o processo de ensino-aprendizagem de uma LE, a saber: 1. o ensino de cultura como um processo interpessoal, no qual os significados emergem por meio da interação social entre os participantes do processo de aprendizagem, sendo um processo dinâmico que inclui os estudantes em práticas sociais. Nesse contexto, os estudantes precisam saber como a língua pode ser usada para criar e representar sentidos no mundo. Para além da transferência de informações entre as

7 Texto original: “[...] promotes rereadings, retellings, multiple interpretations of the same text, multiple modes of meaning making (visual, verbal, gestural, musical) and multiple modalities of expression (spoken, written, electronic)". 
diferentes culturas, deve haver espaço para uma reflexão tanto sobre a sua própria cultura como a cultura-alvo. Deve-se substituir a "[...] apresentação/prescrição de fatos culturais e comportamentos pelo ensino de um processo que implica, ele mesmo, num entendimento da estrangeiridade ou 'outridade"'/8 (KRAMSCH, 1993, p. 206, tradução nossa); 2. o ensino de cultura como diferença, que pressupõe que a cultura não deva ser encarada sob uma visão monolítica, apenas como um conjunto de traços de uma nação ou de seus habitantes, mas de forma globalizada, que considera os diferentes fatores culturais como idade, gênero, etnicidade e classe social de um sujeito. Em síntese, esses princípios reconhecem a língua em sua variedade, o que permite a expansão dos seus recursos linguísticos.

Fundamentando-se em um ensino de língua associado às questões culturais na constituição e representações dos saberes, a reflexão intercultural pode auxiliar o sujeito imerso em outra cultura a superar generalizações que, por vezes, fomentam uma visão simplificada e preconceituosa a respeito do outro. Em contrapartida, é importante reelaborar nossos objetivos ao ensinar uma LE, conforme aponta Moita Lopes (2006), uma vez que lidamos com a formação de um sujeito heterogêneo, fluído, complexo - que se constitui na relação com outros sujeitos, por meio dos processos discursivos - em uma associação ideológica e de poder. Com base na reflexão apontada pelo autor, falta ao ensino de línguas a compreensão sobre os sujeitos envolvidos no processo de ensino-aprendizagem e dos efeitos ocasionados pela globalização, seu impacto sobre a linguagem e identidade.

Assim, a reflexão intercultural é um processo contínuo, que consiste em revisitar o papel do professor e reconhecer novas formas de politização e domínios dinâmicos de conhecimento que, por sua vez, permitam novas formas de pensar e dar respostas às práticas sociais. É um esforço político, que demanda romper com os limites do pensamento moderno e desenvolver práticas de ensino que favoreçam o estudante no exercício das diferentes

8 Texto original: "Replace the presentation/prescription of cultural facts and behaviors by the teaching of a process that applies itself to understanding foreignness or 'otherness'". 
funções dentro de uma língua, não apenas em formato padrão, mas sempre produzindo novos conhecimentos que consideram a vida social.

\section{Metodologia}

Na seção 2 foram apresentados os traços característicos dos indicadores constitutivos da perspectiva intercultural, com base nos estudos de Kramsch (1993), para discutirmos o critério de seleção para as atividades de leitura do LD, bem como as categorias construídas para análise de tais atividades encontradas nos materiais selecionados.

Um levantamento das atividades de leitura encontradas na coleção "Brasil Intercultural" (livro do aluno e livro de exercícios) permitiu identificar algumas temáticas relacionadas à representação de identidade da língua cultura-alvo, por isso elegemos como critério uma temática em comum que aparece nos três volumes da coleção. Diante disso, optamos por analisar a representação do brasileiro e identificamos três conjuntos de atividades:

- Ciclo básico (Unidade 0 - Conhecendo o Brasil)

- Ciclo intermediário (Unidade 03 - Jeitinho Brasileiro)

- Ciclo avançado (Unidade 07 - Coisas Nossas)

Selecionamos tais atividades, pois podemos pensá-las como um "gatilho" para o ensino de PLE acontecer em viés intercultural e permitir que os estudantes reflitam de modo crítico sobre a sua cultura e a cultura-alvo, de modo a evitar preconceitos e exclusões culturais, e promover o reconhecimento da diferença cultural, como explicita Kramsch (1993).

Para isso, construímos categorias com base nos estudos de Kramsch (1993), a fim de analisarmos como as questões culturais vêm sendo tratadas na referida coleção e como podem contribuir 
para a promoção de um ensino intercultural. Desse modo, indicamos para cada uma delas como a interculturalidade pode auxiliar e fortalecer o cumprimento de suas exigências. São elas:

\section{a. Reconhecer se a atividade permite trabalhar o texto como unidade de sentido}

Essa categoria pressupõe perceber se a leitura considera os aspectos históricos, sociais, culturais e locais envolvidos na língua, porque é nesse processo que o estudante passa a compreender outras formas de perceber a realidade e outras maneiras de construir visões de mundo. Portanto, a sala de ensino de LE é percebida como um espaço onde os sentidos presentes na construção da vida social e cultural do leitor são mobilizados no momento da leitura.

\section{b. Identificar se as atividades permitem ensinar a cultura como um processo interpessoal}

Essa categoria pressupõe perceber se as atividades consideram o contexto no qual o estudante está inserido, isto é, se favorecem o uso da língua para criar e representar sentidos no mundo e para além da transferência de informações entre as diferentes culturas. Nesse sentido, deve haver espaço para uma reflexão tanto sobre a cultura-alvo quanto sobre a sua própria cultura.

\section{c. Prospectar se as atividades permitem ensinar a cultura como diferença}

Essa categoria pressupõe a necessidade de fazer alusão aos movimentos de valorização das diferenças e dos questionamentos quanto às identidades nacionais. Nesse caso, a cultura não deve ser olhada apenas como um conjunto de traços ou características de uma nação, mas é necessário considerar os diferentes aspectos socioculturais, como idade, gênero, etnicidade e classe social de um sujeito. 


\section{Amostra de dados: o que vem sendo feito no BI}

Com base nas categorias preestabelecidas, analisamos as atividades de leitura como uma amostra de parte do trabalho realizado com o Bl. Anexamos tais atividades para melhor apreciação dos resultados obtidos.

No ciclo básico, o exercício solicita a leitura de um texto informativo, intitulado de "Inclusão do direito à felicidade na Constituição", de autoria de Nancy Dutra, que informa a respeito de uma proposta de emenda constitucional que inclui como direito do cidadão a "busca pela felicidade". Em seguida, o exercício propõe que os estudantes respondam a questões como:

1. Em sua opinião, o que traz a felicidade?

2. Você considera que é possível medir a felicidade da população?

3. Em seu país, há alguma iniciativa e/ou preocupação em assegurar o direito da busca pela felicidade?

4. Em sua opinião, ao criar uma lei para constituir o direito à felicidade, se reforçaria algum estereótipo referente à felicidade brasileira? Comente.

5. Que estereótipos relacionados ao Brasil você conhece? O que você pensa sobre eles? (BARBOSA; CASTRO, 2014a, p. 9).

As duas primeiras questões mobilizam opiniões que estão apoiadas nas experiências do estudante em sua própria cultura, gerando uma base para a realização de um contraste com a iniciativa de Nancy Dutra. Por sua vez, as questões quatro e cinco introduzem uma reflexão que possibilita associar a visão de felicidade a estereótipos muitas vezes vinculados ao perfil do brasileiro. Além disso, em relação às categorias preestabelecidas, as observações podem ser encontradas no quadro a seguir.

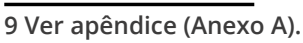




\section{Quadro 5 - Conhecendo o Brasil}

\begin{tabular}{|c|c|c|}
\hline $\begin{array}{l}\text { Reconhecer se a atividade } \\
\text { permite trabalhar o texto } \\
\text { como unidade de sentido }\end{array}$ & $\begin{array}{l}\text { Identificar se a atividade per- } \\
\text { mite ensinar a cultura como } \\
\text { um processo interpessoal }\end{array}$ & $\begin{array}{l}\text { Prospectar se a atividade per- } \\
\text { mite ensinar a cultura como } \\
\text { diferença }\end{array}$ \\
\hline $\begin{array}{l}\text { Observa-se na atividade } \\
\text { que a leitura é trabalhada } \\
\text { como uma habilidade } \\
\text { isolada, na qual o } \\
\text { estudante não estabelece } \\
\text { interação com o texto } \\
\text { para produzir sentidos. } \\
\text { No entanto, para Kramsch } \\
\text { (1993), o texto deve } \\
\text { ser trabalhado como } \\
\text { “unidade de sentido", } \\
\text { pois se constitui a partir } \\
\text { de discursos vinculados } \\
\text { a valores, crenças e } \\
\text { práticas sociais que nos } \\
\text { possibilitam confrontar } \\
\text { visões e negociar } \\
\text { significados, ou seja, não } \\
\text { é somente adquirir as } \\
\text { habilidades funcionais } \\
\text { da língua, mas construir } \\
\text { múltiplas interpretações }\end{array}$ & $\begin{array}{l}\text { Nota-se na atividade que } \\
\text { o enunciado (3) questiona } \\
\text { o estudante quanto às } \\
\text { características de seu } \\
\text { país, para saber se há } \\
\text { alguma iniciativa e/ou } \\
\text { preocupação em assegurar } \\
\text { o direito da busca pela } \\
\text { felicidade, abre espaço } \\
\text { para a comparação de } \\
\text { sua cultura com a cultura } \\
\text { do outro, entretanto, não } \\
\text { permite discutir de forma } \\
\text { crítica as semelhanças e } \\
\text { as diferenças culturais, a } \\
\text { fim de que o estudante } \\
\text { desenvolva uma maior } \\
\text { consciência de sua } \\
\text { própria identidade e } \\
\text { um reconhecimento da } \\
\text { identidade do outro, } \\
\text { conforme Kramsch (1993). }\end{array}$ & $\begin{array}{l}\text { Percebe-se na atividade } \\
\text { que os enunciados (4 e 5) } \\
\text { questionam o estudante em } \\
\text { relação à criação de uma } \\
\text { lei para constituir o direito } \\
\text { à felicidade. Ao perguntar } \\
\text { se o material reforçaria } \\
\text { algum estereótipo referente } \\
\text { à felicidade brasileira (4), } \\
\text { interroga quais estereótipos } \\
\text { relacionados ao Brasil são } \\
\text { conhecidos e o que é pensado } \\
\text { acerca deles, podendo abrir } \\
\text { espaço para que o estudante } \\
\text { reflita em torno dos valores } \\
\text { culturais que são perpetuados. } \\
\text { Contudo, caberia ao professor } \\
\text { desenvolver esse trabalho de } \\
\text { desconstrução, produzindo } \\
\text { novos conhecimentos, novas } \\
\text { formas de enxergar a vida } \\
\text { social. }\end{array}$ \\
\hline
\end{tabular}

de um mesmo texto

(KRAMSCH, 2009).

No ciclo intermediário, o livro de exercício propõe a leitura/escuta da música "Brasileiro", cantada por Ivete Sangalo (Anexo 2). Nesse texto, há elementos culturais que descrevem o brasileiro, com base no "futebol", "samba", "alegria" etc. Em seguida, solicita-se ao estudante que:

1) a. Retire do texto e escreva a seguir elementos culturais que descrevem e caracterizam o povo brasileiro na canção; b. Em duplas, você deve escrever alguns costumes típicos das pessoas de seu país. Logo após, apresente para seu/sua colega e professor (a);

2) Substitua as palavras grifadas no texto por outras que apresentem o mesmo sentido; 
3) Releia o trecho a seguir: "Brasileiro sempre acha algum motivo pra comemorar". [...] Partindo das informações presentes na música de Ivete Sangalo, escreva um texto sobre as características do povo brasileiro [...]. (BARBOSA; SCHRÄGLE, 2014b, p. 18) ${ }^{10}$.

Mais uma vez notamos que a questão 1 propõe uma comparação entre elementos culturais do Brasil e Argentina como referência para a demarcação de elementos distintivos, uma vez que é requerido do estudante o registro de costumes típicos em certos grupos sociais do país em que vive. O Quadro 6 foi organizado para apresentar a análise com base nas categorias.

\section{Quadro 6 - Jeitinho brasileiro}

Reconhecer se a atividade permite trabalhar $o$ texto como unidade de sentido

$\mathrm{Na}$ atividade de leitura, o texto se restringe a um exercício de localização de informações (1-a) como pretexto para ensinar os aspectos linguísticos da língua (2) e para trabalhar a produção escrita (3). Diante disso, percebe-se que a atividade considera a aprendizagem da língua-alvo a partir de suas especificidades formais e não reconhece o leitor como sujeito histórico, vinculado a experiências de ser e agir por meio da língua (KRAMSCH, 1993), pois não permite ao estudante mobilizar sentidos que são construídos ao longo da vida social e cultural.
Identificar se a atividade permite ensinar a cultura como um processo interpessoal

$\mathrm{Na}$ atividade, identificamos que o enunciado (1-b) permite ao estudante falar de costumes típicos do seu próprio país, mas não pressupõe o exercício voltado para a visão da cultura do outro a partir da própria cultura. Segundo Kramsch (1993), deve haver espaço para uma reflexão tanto sobre a língua cultura-alvo quanto sobre a língua cultura-nativa, no entanto, nesta atividade, a visão de cultura recai sob uma visão de que aprender a cultura é aprender apenas informações sobre os hábitos/comportamentos de um determinado país e seus habitantes.
Prospectar se a atividade permite ensinar a cultura como diferença

Esta atividade não reconhece a necessidade de fazer alusão aos movimentos de valorização das diferenças e dos questionamentos quanto às identidades nacionais e não contempla o tratamento de conflitos identitários e de contradições sociais presentes no texto, tais como: etnicidade ("índio, mulato, branco e preto"); gênero ("Ninguém sabe se é homem ou mulher"); religião ("candomblé", "missa"); classe social ("ando de buzu precário", "falta rango, escola"), por exemplo. Assim, precisaria de mais aprofundamento em relação às diferenças e aos fatores listados acima.

10 Ver apêndice (Anexos B e C). 
No ciclo avançado, a atividade apresenta um texto informativo, “Turistas estrangeiros listam as coisas que acharam mais curiosas no Brasil", de autoria de Flávia Mantovani (Figura 3). A matéria do G1 propõe a alguns turistas estrangeiros, recentemente chegados do Brasil, a indicação de hábitos, comidas e outros itens que chamaram atenção quando estiveram no país. O enunciado dessa atividade solicita ao estudante que leia o texto e responda às seguintes questões:

1) Dos itens mencionados pelos estrangeiros que participaram da enquete, qual mais chamou sua atenção e qual menos?

2) Em sua opinião, que características de seu país chama a atenção dos turistas estrangeiros?

3) Que país ou lugar você visitou mais chamou sua atenção? Por quê?

4) Se você tivesse que escolher uma dessas opiniões sobre o Brasil, qual seria a sua? (SCHRÄGLE; MENDES, 2014c, p. 49)11.

Nessa atividade, o estudante tem a oportunidade de comparar as próprias opiniões com as de outros turistas (questões 1 e 2), circunstância que possibilita a ampliação da interpretação relativa aos hábitos e costumes brasileiros. Para realizar a análise com base nas categorias supracitadas, foi organizado o Quadro 7.

11 Ver apêndice (Anexos D, E e F). 


\section{Quadro 7 - Coisas nossas}

Reconhecer se a atividade permite trabalhar o texto como unidade de sentido

Nota-se que a atividade orienta o estudante a percorrer as marcas deixadas pelo autor para chegar à formulação de suas ideias e sentidos (1) e abre espaço para que o estudante se posicione em relação ao tema (4). Ao conduzir o estudante a refletir sobre seu ponto de vista a respeito do tema e a comparar sua opinião com a visão do autor, possibilita um "gatilho" para um ensino intercultural, pois, segundo Kramsch (1993), não há como conceber a leitura sem que haja uma relação extralinguística entre a língua cultura-nativa e a língua cultura-alvo, porque é no confronto que o estudante passa a compreender novas formas de ver a realidade, ocasionando outras maneiras de construir visões de mundo.

\section{Identificar se a atividade per- $\quad$ Prospectar se a atividade per- mite ensinar a cultura como um processo interpessoal mite ensinar a cultura como diferença}

A atividade possibilita ao estudante pensar sobre a cultura do outro a partir de sua própria cultura (2 e 4), mas não permite discutir de forma crítica e reflexiva as diferenças e proximidades culturais, o que Kramsch (1993) considera como crucial para que se construa uma cultura de "terceiro espaço". Assim, a atividade não considera o estudante como um ator social capaz de mudar o seu entorno por meio da linguagem. Isso porque aprender uma língua presume ir além da transferência de informações entre as diferentes culturas, pois tem como princípio de base criar e representar sentidos no mundo, evitando que preconceitos e exclusões culturais se perpetuem.

Ainda que o texto apresente uma visão de cultura restrita aos hábitos/comportamentos e elementos representativos da língua cultura-alvo, aborda diferentes opiniões em relação a esses aspectos, indo além de construções estereotipadas que também estão presentes no texto, tais como: "Há muitos brasileiros acima do peso do que imaginávamos" ou como "Ficamos surpresos por ouvir pouca música brasileira e muita música pop americana". Assim, a atividade, se readequada, poderia incentivar o estudante a reconhecer as diferenças na cultura-alvo e descontruir certas visões que muitas vezes já preexistem em relação à cultura do outro.

Fonte: Elaboração própria (2019).

A partir da análise empreendida, pudemos avaliar a produtividade das categorias indicadas para análise das atividades de leitura no $B I$, uma vez que auxilia o professor a compreender como o LD poderia ser utilizado como um apoio pedagógico e ainda perceber as suas limitações. Nesse viés, é possível observar que, ao se interessar em reconhecer o texto como unidade de sentido e buscar ensinar a cultura como um processo interpessoal e como diferença, o professor poderia orientar os estudantes a refletir de modo crítico, propondo questões que possam romper com certas visões cristalizadas em relação à sua própria cultura e à cultura-alvo, a fim de desenvolver uma maior consciência de sua própria identidade e o reconhecimento da identidade do outro. 
Nesse sentido, seria relevante compreender tais categorias como norteadoras para um possível processo de ensino-aprendizagem acontecer em viés intercultural, o que significa dizer que, por meio de diálogos comparativos, os estudantes poderiam desconstruir crenças e pontos de vista, que por vezes segregam certas culturas e valorizam outras de maneira hegemônica. Ao discutirem acerca das diferenças e semelhanças nesse confronto entre-culturas de modo crítico e reflexivo, seria possível, então, considerar os diferentes aspectos socioculturais de cada sujeito e dos grupos sociais, a fim de construir outros novos sentidos.

Com base na análise realizada e nas discussões propostas, tecemos as considerações finais do artigo.

\section{Considerações finais}

A coleção Brasil Intercultural indica um avanço no que diz respeito à produção de LD para hispanofalantes, pois demonstra se interessar pelas questões culturais tanto da língua cultura-alvo como da língua cultura-nativa. No entanto, certas atividades não colaboram para o desenvolvimento de uma reflexão crítica do estudante acerca do outro, pois não ampliam a sua visão de mundo nem possibilitam discussões acerca das aproximações e diferenças culturais. Ademais, ao se perpetuar uma visão estereotipada em relação à cultura-alvo, ao apoiar-se na representação do brasileiro por meio de estereótipos, há ausência de questões que problematizem isso, exceto na primeira atividade proposta, que questiona tais visões estereotipadas.

Assim, parece ser indicado ao professor que utilizar a referida coleção identificar atividades de leitura que possam auxiliar o desenvolvimento da interculturalidade em sala de aula. Para isso, podemos pensar na readequação das atividades propostas, a fim de que isso possa contribuir para o posicionamento crítico do estudante, em contraste com a sua cultura e com a do outro, de modo a evitar generalizações, preconceitos e exclusões culturais. 


\section{Referências}

ALMEIDA, A. BARBOSA, C. N. Horizontes: RUMO À PROFICIÊNCIA EM LínGUA portuguesa. Buenos Aires: LiBreAr, 2010.

ARgentina. Contenidos Básicos Comunes. Disponível em: http://www. BNM.ME.GOV.AR/GIGA1/DOCUMENTOS/EL001215.PDF. ACESSO EM: 20 FEV. 2019. ARgentinA. Decreto n. 25.181, de 27 de outubro de 1999. Aprova o Convênio de Cooperação Educativa entre a República Argentina e a República Federativa do Brasil. Buenos Aires: Senado e Câmara dos Deputados. DispoNÍVEL EM: HTTPS://BIT.LY/34OU3LR. ACESSO EM: 21 MAIO 2019.

ARgentina. Decreto n. 26.206, de 14 de dezembro de 2006. Dispõe SOBRE A OBRIGATORIEDADE DE CONTEÚDOS CURRICULARES DE LE RELACIONADOS AO Mercosul. Buenos Aires: Senado e Câmara dos Deputados. Disponível em: HTTPS://BIT.LY/36YE4YX. ACESSO EM: 11 ABR. 2019.

ARGENTINA. Decreto N. 26.468, de 17 de dezembro de 2008. Dispõe sobre a obrigatoriedade da oferta do Português como Língua Estrangeira na

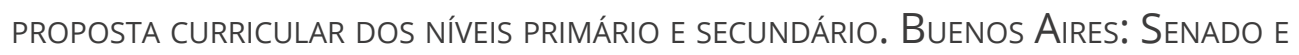
CÂmara dos Deputados. Disponível em: https://bit.ly/34BvVwD. Acesso em: 18 MAR. 2019.

ARGENTINA. MERCOSUR EDUCACIONAL. DisponíveL EM: HTTP://EDU.MERCOSUR.INT/PT-BR/. ACESSO EM: 15 MAR. 2019.

ARgentinA. Ministerio de Relaciones Exteriores y Culto. República ArGENTINA. DisPoníVEL EM: HTTPS://WWW.MRECIC.GOV.AR/. ACESSO EM: 24 MAIO 2019.

ARGENTINA. Secretaria de politicas universitarias. Disponível em: https:// BIT.LY/36EGURK. ACESSO EM: 14 MAIO 2019.

ARgentinA. Setor Educativo. Protocolo de intenciones de los ministros de Educación, 1991. Disponível em: htTps://Bit.ly/2PFBWE9. Acesso em: 24 JAN. 2019.

\section{ASSOCIÁCION ARGENTINA DE PROFESORES DE PORTUGUÉS.}

Disponível em: htTPS://Aapp.Webnode.com/. Acesso em: 18 mar. 2019.

BARBOSA, C. N.; SCHRÄGLE, I. Brasil Intercultural: Língua E CULtura brasileira para estrangeiros. Ciclo Intermediário - Níveis 3 e 4. Coordenação Edleise Mendes. Buenos Aires: Casa do Brasil, 2014b. 
BARBOSA, C. N.; CASTRO, G. N. De. Brasil Intercultural: Língua e CULtura brasileira para estrangeiros. Ciclo Básico - Níveis 1 e 2. Coordenação Edleise Mendes. Buenos Aires: Casa do Brasil, 2014A.

Brasil. Centro Cultural Brasil-ARgentinA. Disponível em: http:// CCBA.ITAMARATY.GOV.BR/PT-BR/. ACESSO EM: 15 MAIO 2019.

BRASil. Decreto n. 9394. Lel de Diretrizes e Bases da Educação Nacional. Brasília: PresidênCia da República, Casa Civil, 1996. Disponível em: https:// Bit.Ly/33deE5Z. Acesso em: 20 feV. 2019.

BRaSil. Ministério das Relações Exteriores. Governo Federal. Disponível EM: HTTP://WWW.ITAMARATY.GOV.BR/PT-BR/. ACESSO EM: 26 FEV. 2019.

CONSElHo dA EUROPA. Quadro Europeu Comum de Referência para as Línguas - aprendizagem, ensino, avaliação. Trad. por Maria Joana Pimentel do Rosário e Nuno Verdial Soares. Porto: Edições Asia, 2001.

CRISTOFOLI, M. S. Políticas de línguas estrangeiras na educação básica, Brasil e Argentina entre avanços e percalços. Dissertação (Doutorado) Universidade Federal do Rio Grande do Sul, Porto Alegre, 2010. Disponível EM: HTTPS://BIT.LY/2pCJKAE. ACESSO EM: 23 ABR. 2019.

DINIZ, L. R. A ET AL. UMA ANÁLISE DE LIVROS DIDÁTICOS DE PORTUGUÊS PARA ESTRANGEIROS. IN: DIAS, R; CRISTÓVÃO, V. L (ORG.). 0 LIVRo didÁtICO de LÍNGUA estrangeira: múltiplas Perspectivas. Campinas: Mercado de Letras, 2009. P. 265-304.

FUnCEB. Um português bem brasileiro. Buenos Aires: Loyola, 1997.

FUnCEB. Conhecendo o Brasil curso de português para falantes de espanhol. Buenos Aires: Akian Gráfica Editora, 2000.

GONZALEZ, V. A. Análise de abordagem de material didático para o ensino de línguas (PLE/PL2). Dissertação (Mestrado) - Universidade de Brasília, Brasília. 2015. DisPonível em: htTP://Repositorio.unB.BR/HANDLE/10482/18084. ACESSO EM: 20 AGO. 2018.

HALL, S. Quem precisa da identidade? Tradução de Tomaz Tadeu da Silva. In: SILVA, Tomaz Tadeu da (org.); HALL, Stuart; WOODWARD, Kathryn. Identidade e diferença: a Perspectiva dos estudos culturais. Petrópolis, RJ: EdiTORA Vozes, 2009. P. 103-133. 
KRAMSCH, C. Context and Culture in Language Teaching. Oxford: OxFORD, UNIVERSITY PRESS, 1993.

KRAMSCH, C. Third Culture and Language Education. In: COOK, V.; WEl, L. (ed.). Contemporary Applied Linguistics. London: Continuum, 2009. p. 233-254.

KRAMSCH, C. Cultura no ensino de língua estrangeira. Tradução de Orison Marden Bandeira de Melo Júnior. Revista Bakhtiniana, São Paulo, v. 12, N. 3, P. 134-152, SET./DEZ. 2017 [2013]. DISPONÍVEL EM: HTTPS://BIT.LY/34P1YCS. ACESSO EM: 15 MAR. 2018.

MARÍA, M. M. S.; ANDRÉ, S. Português dinÂmico: nível INTERMediário. Buenos Aires: El Autor, 2010.

MARÍA, M. M. S.; ANDRÉ, S. Português dinÂmico: nível inicial. Buenos Aires: El AUTOR, 2011.

MOITA LOPES, L. P DA. IDENTIDAdes FragmentadAs: A CONSTRUÇÃO DE RAÇA, gênero e sexualidade na sala de aula. Campinas, São Paulo: Mercado de LeTRAS, 2002.

MOITA LOPES, L. P da. Por uma Linguística Aplicada Indisciplinar. São PAulo: Parábola, 2006. P. 67-84.

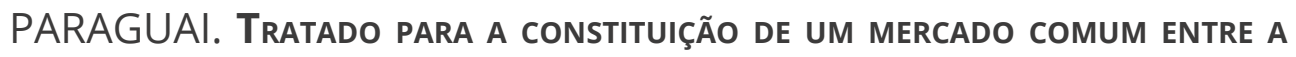
República Argentina, a República Federativa do Brasil, a República do Paraguai e a República Oriental do Urugual, março de 1991. Disponível EM: HTTPS://BIT.LY/2WJUSTF. ACESSO EM: 14 MAIO 2018. 


\section{Anexos}

Anexo a- conhecendo o brasil

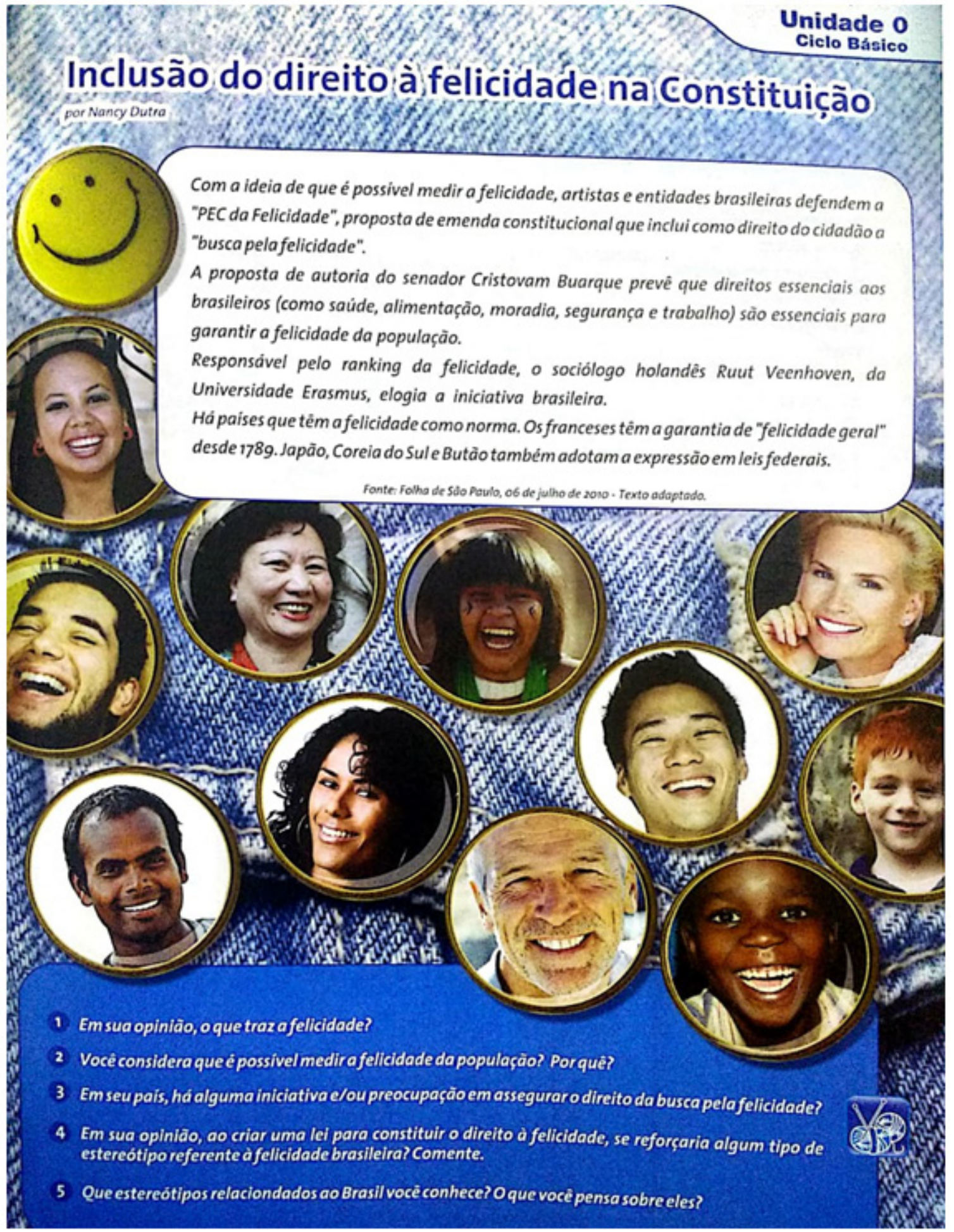




\section{Anexo $b$ - jeitinho brasileiro - PARTE I}

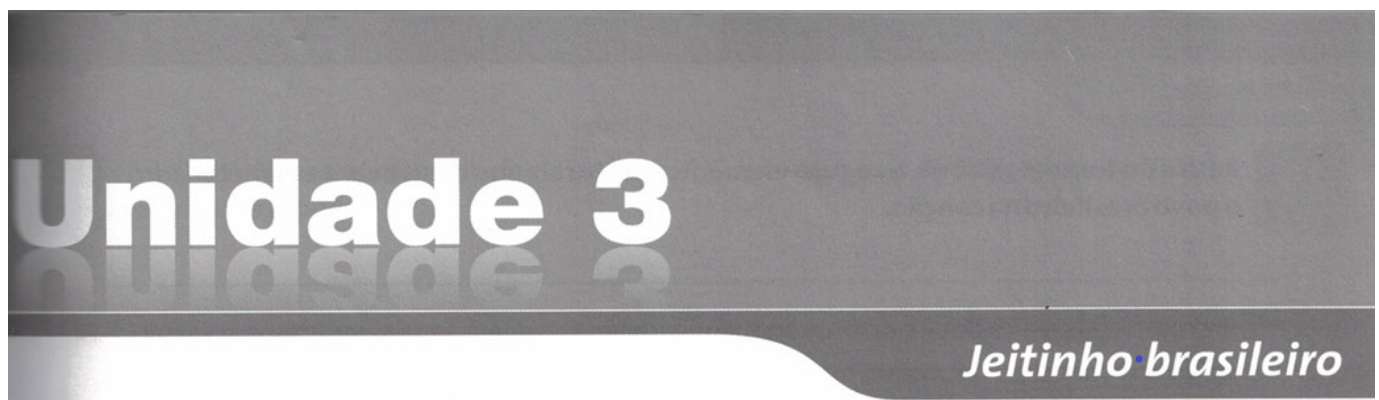

1 Leia/escute a música “Brasileiro", de Ivete Sangalo, e faça o que se pede.

\section{Brasileiro}

Fim de semana, todo brasileiro gosta de fazer um som Uma cerveja bem gelada

Violão de madrugada, samba e futebol

Eu trabalho o ano inteiro

De janeiro a janeiro e não me canso de plantar Ô ôôô

Passa boi, passa boiada

Debruçada na janela, que vontade de cantar

Eu sou brasileiro

Índio, mulato, branco e preto

Eu vou vivendo assim

Eu sou batuqueiro (Cafuzo)

Ando de buzu precário, tão pequeno o meu salário

Na vitrine é tudo caro e assim mesmo quer sorrir

Reza pra todos os santos

São Vicente, São Jerônimo

Vai atrás de um pai-de-santo pro barraco construir

No domingo tem preguiça

Vou com fé, eu vou à missa

E na segunda ao candomblé

Ó, que linda criatura

Não entendo essa mistura, com esse tal de silicone

Ninguém sabe se é homem ou é mulher

Doze meses de agonia

Chegou na periferia com o presente de Natal (legal)

Dou comida à molecada

Mando brincar na calçada

Tá na hora do jornal

Falta rango, falta escola

Falta tudo a toda hora

Tá na hora de mudar

Vivo nessa vida dura

São milhões de criaturas

Brasileiro sempre acha algum motivo pra comemorar.
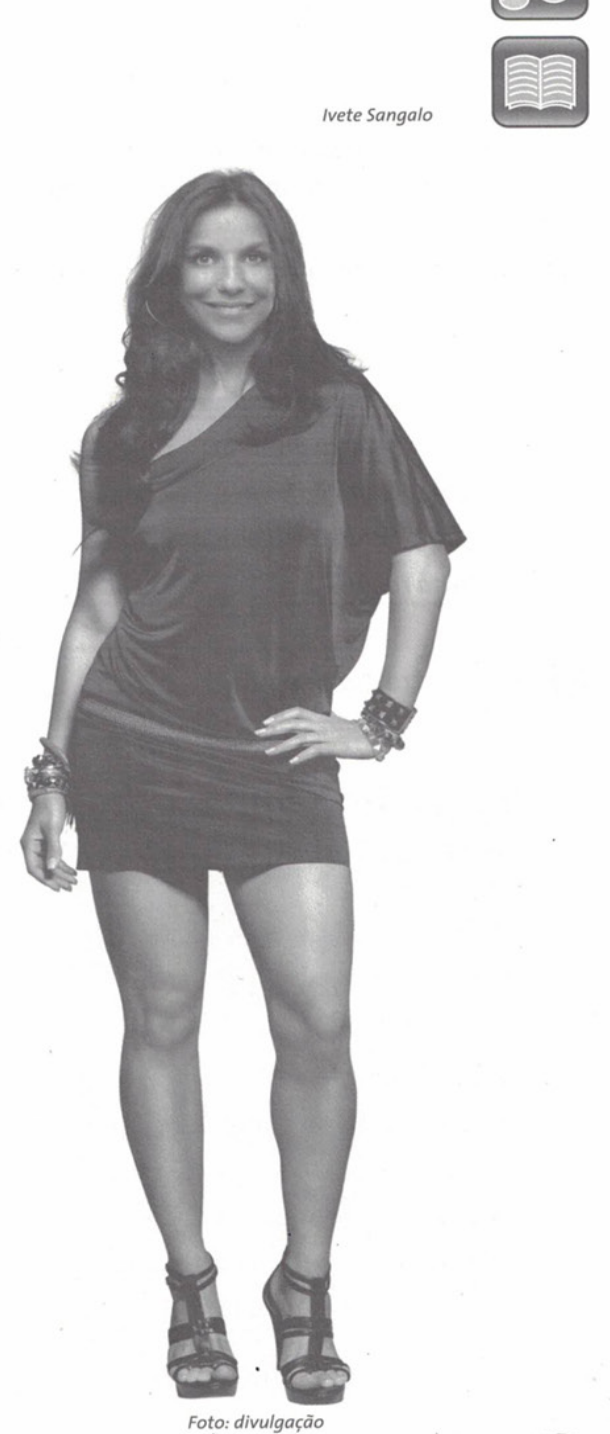


\section{Anexo c - jeitinho brasileiro - PARTE II}

a) Retire do texto e escreva, a seguir, elementos culturais que descrevem e caracterizam o povo brasileiro na canção.

b) Em duplas, você deve escrever um pequeno texto, elencando alguns costumes típicos das pessoas de seu país. Logo após, apresente para seu/sua colega e professor (a).

2 Substitua as palavras grifadas no texto por outras que apresentem o mesmo sentido.
a) Fazer um som
b) Debruçada na janela
c) Ando de buzu precário
d) Chegou na periferia
e) Dou comida à molecada
f) Falta rango

3 Releia o trecho a seguir:

\section{"Brasileiro sempre acha algum motivo pra comemorar."}

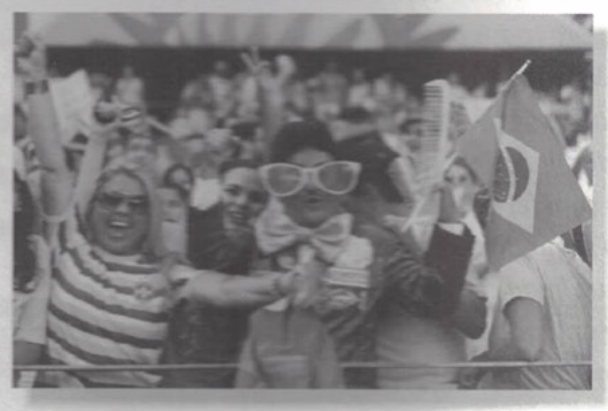

Como estudante de Português Língua Estrangeira (PLE), você participará de um concurso de redação, cuja temática deve abranger a frase "Brasileiro sempre acha algum motivo pra comemorar".

Partindo das informações presentes na música de Ivete Sangalo, escreva um texto sobre as características do povo brasileiro. Lembre-se que o concurso busca avaliar a capacidade de expressão escrita e o conhecimento dos estudantes acerca da cultura brasileira. 


\section{Anexo d - coisas nossas - PARTE I}

(4) Leia o texto a seguir e responda às perguntas.

\section{Turistas estrangeiros listam as coisas que acharam mais curiosas no Brasil}

Eles citam apego à família, preço alto e popularidade de música dos EUA. Beleza natural, comida e receptividade foram ponto alto para a maioria.

Flávia Mantovani

Certos costumes são tão arraigados no dia a dia dos habitantes de um pais que é preciso um ol har de fora para lançar luz sobre eles. Foi o que fez'Olivier Teboul, um francês que mora em Belo Horizonte e que escreveu um post em seu blog pessoal listando 65 "curiosidades brasileiras".

$[\cdots]$

Suas observações sobre o Brasil ("às vezes um pouco exageradas", avisa) vão de questões bem conhecidas por quem mora aqui - a quantidade de filas, o prato típico à base de arroz e feijão, o gosto por novelas - até outros häbitos que podem parecer universais para nós, mas surpreendem quemé de outro pais.

Entre eles, a possibilidade de pedir pizza meio a meio ("ideia simples e genial", diz o post), o costume de aproximar o valor do pagamento do táxi, de escovar os dentes no trabalho e de não tocar comida com as mãos, recorrendosempreaoguardanapo.

o G1 propôs a alguns turistas estrangeiros que estiveram recentemente no pais um exercicio parecido: listar hábitos, comidas e outros itens que chamaram sua atenção quando estiveram aqui.

Oresultado revela desde o encantamento com as belezas naturais, a comida e a receptividade das pessoas atéa surpresa por ouvir mais música americana do que brasileira, pagar caro pela hospedagem ou ver três passageiros namesma moto-sem capacete.

Confira a seguiroque eles disseram.

\section{NATALIA RUMYANTSEVA, 35 anos, professora de inglês.}

País de origem: Rússia.

Quandoesteve no Brasil: Em julho de 2011 e entrejunhoe julhode 2012.

Quais cidades visitou: Belo Horizonte, Rio de Janeiro, Serra do Cipó (MG), Santa Bárbara (MG), Ouro Preto (MG).

Por que quis conhecer o pais: "Foi o amor que me levou para ai: me apaixonei por um músico brasileiro. Hoje não estamos mais juntos, mas graças a ele conheci muita gente interessante, fiz amigos e aprendi um pouco de português."

Oque chamou sua atenção:

- A diversidade de pessoas: gente com diferentes tipos de pele, de cabelo. Foi a primeira vez que conheci "morenos". Na Rússia as coisas são diferentes.

- Comida! Sem palavras! [Natalia escreveu essa frase em português] É incrivel, saborosa, chama a atenção pela sua aparência agradável e colorida. Ee é boa para a digestão. Comi muito e nunca ganhei peso. Melhor ainda: os homens no Brasil são os cozinheiros perfeitos.

- Pessoas amigáveis e abertas. Todo mundo dizendo "Boa tarde!", "Tudo joia?". E, claro, sorrisos bonitos e abertos. Tenhocerteza de que apenas os brasileiros têm esse sorriso.

- Cachaça. Não consigo evitar mencioná-la. Aqui eu nunca tinha visto essa bebida. Adorol O que mais posso dizer? [...]

- Percebi que quando os brasileiros tiram fotos eles se agrupam juntos quando posam. Achei isso muito especifico, essa posição em que todos ficam juntos.

- Conheci frutas e vegetais que nunca tinha visto. Jaca, maxixe, chuchu! E essa não é a lista completa. Trouxe sementes de maxixe e meu pai conseguiu fazê-las brotar em sua horta na Sibéria! 


\section{Anexo e - coisas nossas - PARTE II}

BROCK WILSON, 34 anos, advogado, e DEIRDRE FITZ-WILLIAM, 31 anos, enfermeira. Pais de origem: Estados Unidos. Quando estiveram no Brasil: Entre 17 de março e 17 de abril deste ano.

Quais cidades visitaram: Florianópolis (SC), Ilha Grande (RJ), Paraty (RJ), Búzios (RJ), Trindade (RJ), Arraial do Cabo (RJ), Rio de Janeiro, São Paulo, Foz do lguaçu (PR).

Por que quiseram conhecer o pais: O Brasil era parte do roteiro do casal em uma viagem pela América do Sul $e$ Central.

- A sociedade como um todo cuida bastante das mulheres. Por exemplo, encontrei um homem gritando obscenidades no lobby do meu hotel e o homem perto dele brigou não por ele estar falando palavrões, mas por ter feito isso na frente de uma dama.

80 Adorei o vagão só para mulheres do metrô do Rio! Tornou a experiência de circular na hora do rush bem melhordoque em outras cidades.

- No Brasil as pessoas trabalham para viver, e não vivem para trabalhar. Há um foco em aproveitar a vida e a familia e, ao menos no Rio ena Bahia, em mantero bem-estar fisico, mental e espiritual.

- Nunca tinha visto um lugar onde a natureza se mistura tanto com as cidades e a vida diária. [...] 


\section{Anexo f - coisas nossas - PARTE III}

\section{Unidade 7}

Fonte: MONTOVANI, Flávia. Turistas estrangeiros listam as coisas que acharam mais curiosas no Brasil

Disponivel: http://g1.globo.com/turismo-e-viagem/noticia/2013/04/turistas-estrangeiros-listam-coisas-que-acharam-mais-curiosas-nobrasil.html. Acessado em julho de 2014 .

a) Dos itens mencionados pelos estrangeiros que participaram da enquete, qual mais chamou sua atenção equal menos?

b) Em sua opinião, que características de seu pais chamam a atenção dos turistas estrangeiros que o visitam? Dê exemplos.

c) Que pais ou lugar que você visitou mais chamou sua atenção? Por quê?

d) Se você tivesse que escolher uma dessas opiniões sobre o Brasil, qual seria a sua? Por quê?

5 Imagine que você trabalha como redator (a) em uma revista de turismo, e foi incumbido de escrever um artigo sobre 'o que chama a atenção do estrangeiro no Brasil'. Você pode usar as informações da atividade anterior para alimentar seu texto.

6 Leia o texto a seguir sobre a criação do Candomblé e depois faça o que se pede:

\section{Mitologia dos Orixás}

No começo não havia separação entre

o Orum, o Céu dos orixás,

e o Aiê, a Terra dos humanos.

Homens e divindades iam e vinham,

coabitando e dividindo vidas e aventuras.

Conta-se que, quando o Orum fazia limite com o Aiê,

um ser humano tocou o Orum com as mãos sujas.

O céu imaculado do Orixá fora conspurcado.

O branco imaculado de Obatalá se perdera.

Oxalá foi reclamar a Olorum.

Olorum, Senhor do Céu, Deus Supremo,

irado com a sujeira, o desperdicio e a displicência dos mortais,

soprou enfurecido seu sopro divino

e separou para sempre o Céu da Terra.

Assim, o Orum separou-se do mundo dos homens

e nenhum homem poderia ir ao Orum e retornar de lá com vida.

E os orixás também não podiam vir à Terra com seus corpos.

Agora havia o mundo dos homens e o dos orixás, separados.

Isoladas dos humanos habitantes do Aiê, as divindades entristeceram.

Os orixás tinham saudades de suas peripécias entre os humanos

$e$ andavam tristes e amuados.

Foram queixar-se com Olodumare, que acabou consentindo

que os orixás pudessem vez por outra retornar à Terra.

Para isso, entretanto, teriam que tomar o corpo material de seus devotos.

Foi a condição imposta por Olodumare $[\ldots]$

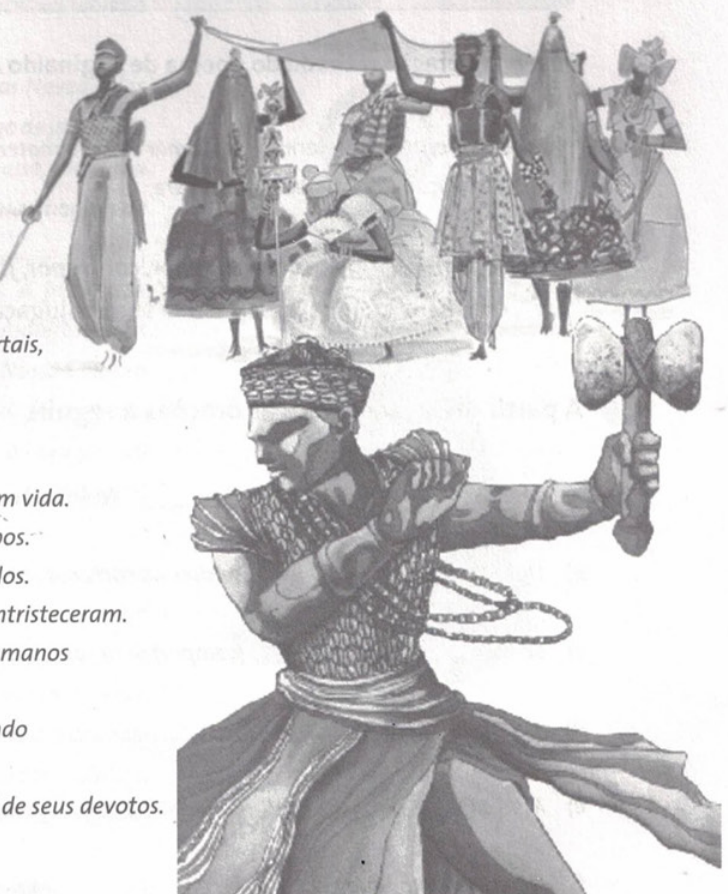

